was mutually adopted by the unanimous agreement of all the parties.

Attempts were made to lay these new proposals before Lord Balfour's Committee, but a reply was received to the effect that the Committee had by that time ceased to take evidence, and nothing could be done. This is particularly to be regretted, because the improved Bill meets many of the difficulties mentioned in the Committee's report.

The new Bill has just been before the House of Lords, and consideration of it has been postponed on the understanding that the Government will institute an inquiry into the whole question. The Bill received widespread and influential backing, having been introduced by the Association of Chambers of Commerce of the United Kingdom (representing more than x30 Chambers throughout the country), and supported by the Decimal Association and many organisations representative, among others, of :-Finance, the Institute of Bankers; Commerce, Chambers of Commerce; Industry, Federation of British Industries; Science, British Science Guild; Transport, Municipal Tramways Association; and many professions and trades. This unanimity of organised opinion augurs well for the eventual adoption of a reform which, as hinted at by the Committee, has possibly suffered more hitherto from the diversity of advice tendered by its advocates than from any real opposition either in or out of Parliament.

Harry AllCOCK.

\section{PROGRESS OF THE EDUCATION BILL.}

$D$ ESPITE the pressure of other urgent measures and the consequent limitations as to time, and in spite also of the persistent opposition of certain Members, good progress is being made with the Education Bill in the Honse of Commons. Already clause Io, the crucial clause of the measure, which is to secure the continued education of young persons from fourteen to eighteen years of age who have entered into employment, has been reached. It is to be hoped that the endeavour of $\mathrm{Mr}$. Fisher to preserve the contact of adolescent youth with the humaner side of life during these formative years, whilst giving effect to all reasonable opportunities for enhancing both knowledge and aptitude in the chosen vocation, may receive complete support and be assured of legal enactment.

It is in this connection satisfactory to find that the great evil of half-time, which has mainly characterised the textile industrial areas of the country, has found little support in the House, and clause 8, section I, abolishing all exemptions up to the completion of the fourteenth year of age (to come into operation on the close of the war), has been passed without a division. We thus secure that the child in the elementary school will now have at least a complete preliminary course of education and training from the beginning of his sixth to the completion of his fourteenth year, and the nation comes into line with the more advanced industrial and commercial nations of the Continent who are its greatest rivals.

Moreover, liberty to raise the school age until the completion of the fifteenth year of age, with or without exemptions, at the option of the local education authority has secured the assent of the Committee by a very large majority, and it is further provided that adequate provision shall be made in order to secure that children and young persons shall not be debarred from receiving the benefits of any form of education by which they are capable of profiting through inability to pay fees. In view of the necessity of encouraging the development of higher education in county areas, it is satisfactory to find that there was unanimous assent to the abolition of the limit of expenditure from the rate by county council committees.

NO. 2536 , VOL. IOI]
Provision is made for the due inspection of privare schools with a view to the elimination of unsatisfactory establishments by bringing them under the direct supervision of the local authorities and of the Board of Education. A step has also been taken at the option of the local education authority to raise the compulsory age of entrance to the elementary school from five to six years, provided that adequate provision is made in the area for the establishment of duly equipped nursery schools. It is a pleasant thing to note that in the establishment by scheme of joint, committees teachers are expressly named as eligible for co-optation. The efforts of the friends of this important measure should now be firmly concentrated upon the provisions of clause Io, so as to secure that the proposals of $\mathrm{Mr}$. Fisher, who has so far piloted the Bill with such admirable tact, shall be given legislative effect. Whatever be the merits of the Hibbert amendment; and they are by no means absent, they are not comparable with the advantages to be gained by the intimate association of young persons with the beneficial influence of the schools up to the conclusion of their eighteenth year.

\section{ORGANISATION OF GLASS INDUSTRIES.}

THE Society of Glass Technology held an important meeting at the Institute of Chemistry on May I5. when the president, Mr. Frank Wood, in opening a discussion on "The Glass Industry after the War," advocated the formation of trade councils for the organisation of the various sections. He proposed that a federation should be formed, controlled by a council consisting of sectional representatives, both manufacturers and men, together with representatives of science, the Government, and finance. The matter should be taken in hand immediately, and every effort made to secure workmen and machinery to enable the country to supply all its requirements, instead of about 20 per cent. in pre-war days. To do this, Government assistance is necessary. Without protection in some sections and prohibition in others, there would be a deluge of foreign glass just when their furnaces and shops ought to be undergoing repair and when time would be required for the training of workers. They should be ready for the future, and the Optical Munitions and Glassware Supply Department of the Ministry of Munitions, to which they were so much indebted, should continue in being to help them. Mr. Connolly voiced the need for a dump-proof Empire in order that a fair chance might be given to home production. Sir Frank Heath dealt with the necessity for bringing science to bear on the matter, assuring the meeting of the desire of the Government to assist research through industrial organisations. The conditions under which grants are made are not onerous, and the researches are conducted free from meticulous interference from headquarters. Mr. Douglas Baird referred to the production of chemical ware, which will not be able to stand on its feet for some time without the aid of "foster-parents." Sir Herbert Jackson spolse hopefully of the general outlook. National prestige must supply the stimulus for pulling together after the war. Their representatives should be brought into collaboration with Government representatives to deal with the problems before them. $\mathrm{Mr}$. Biram, of the Ministry of Munitions, acknowledged the great help of the manufacturers in the production of war material; the future would call for all their energy and enterprise. Dr. Rosenhain appealed for the fullest utilisation of scientific results and the interchange of knowledge and experience. Mr. S. N Jenkinson said that the industry must make itself efficient if it is to be supported by the Government. Many other members joined in the discussion, and it 